\title{
Dermacentor Reticulatus Biorhythms in the Northern Forest-Steppe of the Tyumen Region
}

\author{
Yuri Valerievich Glazunov \\ candidate of biological sciences, associate professor, \\ ASRIVEA - Branch of Tyumen Scientific Centre SB RAS \\ 2 Institutskay, Tyumen, Russia \\ E-mail: glazunovurii@mail.ru
}

\author{
Larisa Aleksandrovna Glazunova \\ candidate of veterinary sciences, associate professor, \\ FSBEI HE Northern Trans-Ural SAU \\ 7 Respubliky, Tyumen, Russia \\ E-mail: glazunovala@gausz.ru
}

\begin{abstract}
Toforecast thenumberof ticks and take successful measures for decreasingthemin population it is necessary to know the features of their phenology in aparticular region. The majority of acarologists pays attention to the features of Ixodes persulcatus'activity as they transmitixodic infections. The proved epizootic and epidemiological importance of Dermacentors dictates the necessity of developing and organizing the comprehensive control system against this specie of ticks toprevent diseases.This demand the fullest and comprehensive studying of ecology and phenology features of Dermacentor reticulatus of a particular region. The aim of the research isthe detailed studying of bioecology of Dermacentor reticulatus ticks, the most widespread ticks in the Tyumen region.

We had monitoredover thelife cycle features of Dermacentor reticulates in natural biotopes over the 2013 to 2014 period in the subzone of the northern forest-steppe of the Tyumen region.

In natural climatic conditions of the specified climatic zone Dermacentor reticulatus are capable to give one generation per a parasitizing season ifparasite juvenile forms meet feeders. The whole process of reproduction from egg up to theadult specimen emerge took from 69 to 161 days, and averagely $115 \pm 1,99$ full days. Metamorphosis of larvae had taken the shortest time period $(29,1 \pm 2,0$ full days or $25,3 \%$ of all cycle time), nymph and imago formations had happened practically for equal periods of $34,5 \pm 2,3$ and $37,0 \pm 5,0$ full days respectively. Having studied the regularities of the Dermacentor reticulates life cycles we can prove the emergence and the activity peaks of both juvenile, and adult phases of these ticks activity. That allows to plan actions oncontrolling these parasites in places of their dwelling.
\end{abstract}

Key words-ixodidae; Dermacentor reticulatus; biorythms, biotope; feeder; egg-laying; metamorphosis, the Tyumen region.

\section{INTRODUCTION}

Nowadays, according to the statisticsthe infectious diseases with a natural nidality remain the most dangerous in every respect and cause concern with close attention of many scientists and practicians $[1,3,7,16,17]$. Therefore, it calls for comprehensive studying infectious diseases and developingscience-based reasonable anti-epizootic and antiepidemic actions on a. All this allows not only to expect scientifically, but also to prevent the emergence and spread of many infections, including those which are transferred by ixodidticks $[9,10,11]$.

Ixodidticks have great medical and veterinary value. It is defined by their vector-borne transmission of many most dangerous pathogens for humans and farm animals. It is considered that the list of the expert diagnosed diseases transmitted by ixodidticks isnot nearly complete $[2,4,5,12$, 13].

At a complication of epidemiologic and epizootologic situations on tick-borne infections it is necessary to startconducting series of measures directed to localization of center of infectionas soon as possible. The priority measures in this case are the treatment of natural biotopes and animalsbyhighly effective acaricides, but at the same time it is necessary to know life cycle of a parasite in details as it can be influencedby abiotic and biotic factors $[14,15]$.

In recent years most of researchers have turned their focus toward studying the features of lifecycles and biological rhythms of Ixodesticks as they have been considered as the main vector force of spreading tick-borne infections until recently. Lately in press there is much more information about participating Dermacentor ticks in this process $[6,8]$.

TakingintoaccountthewidespreadingofticksDermacentorret iculatusintheTyumenregionandtheirprovedactiveinvolvementi nsavingandtransmittingthe tick-borne encephalitis virus, Borrelia, Anaplasma and Babesia, it is necessary to study the peculiarities of life cyclesof these tick speciesto control the situationin epizootic and epidemiologic processes $[4,5]$.

\section{MATERIALS AND METHODS}

The experimental part of the study has been carried out by the Russian National Research Institute of veterinary entomology and arachnology in the laboratory of acarology under support of Programme of fundamental researchof the RAS, project IX. 135.2.3, as well asby theNorthern Trans-Ural State Agricultural University at the department of infectiousandinvasion diseases.

Wehadobserved the life-cycle features of ticks Dermacentor reticulates in natural biotopes over the 2013 to 2014 period.

Fortrialestablishmentofticksinnaturalconditionsthey werecaughtin natural stations in the first decade of September (autumn activity peak). To study the ixodida es'capacity of survival in winter period they were fed on laboratory animals (rabbits) andwere put into cages specially preparedfor that experiment (Figure1-3). 


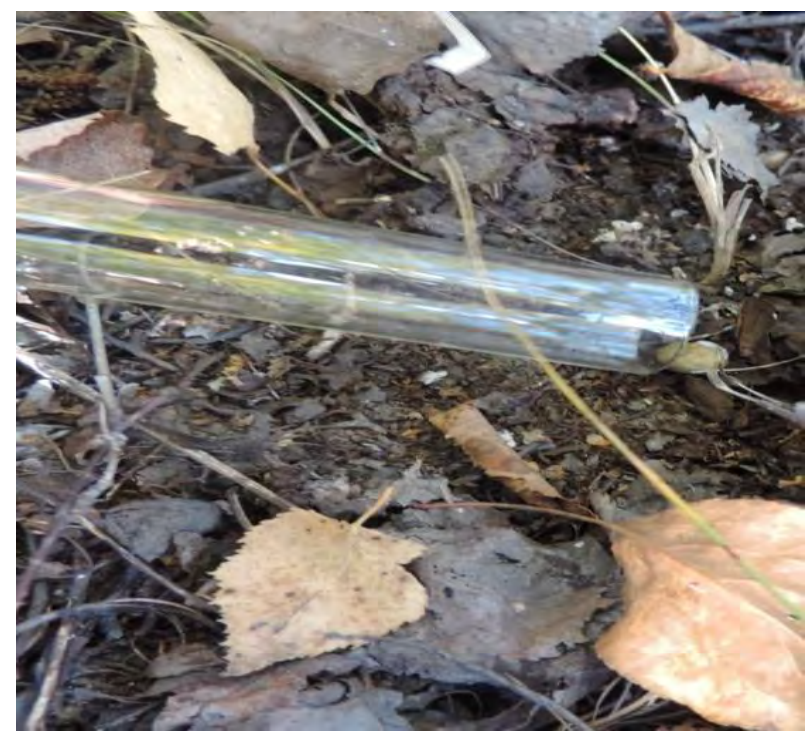

Fig. 1. Moving of congested female tick into forest litter

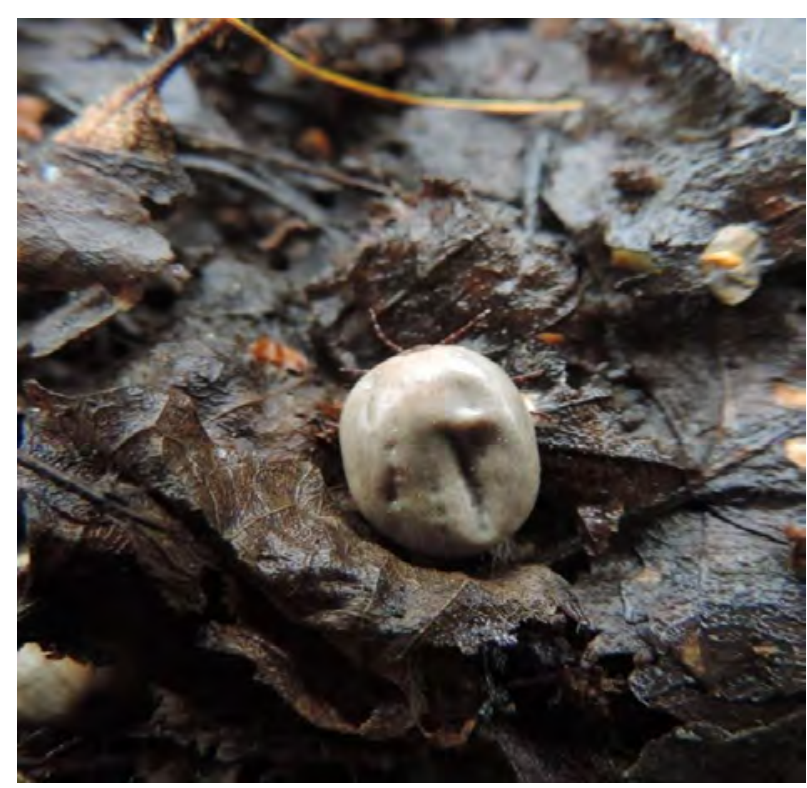

Fig. 2. Female tick Dermacentorreticulatus innatural conditions

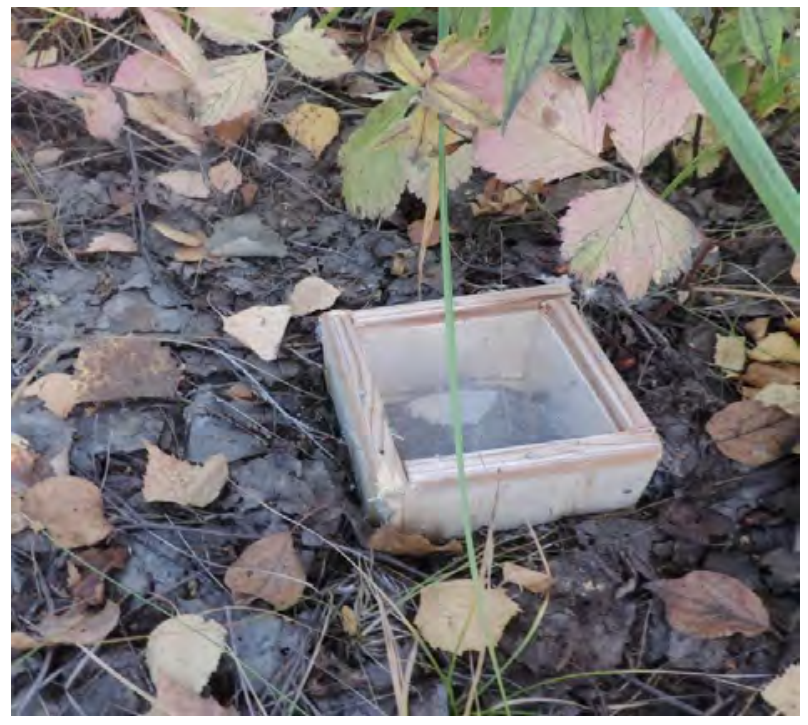

Fig. 3. Woodencage with the female tick D. reticulatus

Eachcongestedfemalewasputintoan individualcage, which was stationed atdiscount area in biotopefor wintering. The female ticks were puton September 19, 2013at the air temperature of $11,3^{\circ} \mathrm{C}$ andrelative humidity of $90 \%$.

\section{RESEARCH RESULTS}

The female ticks were under observation during the ixodidaes' activity season. Asaresult,we have established that none female could lay eggs in autumn period (Figure4-5).

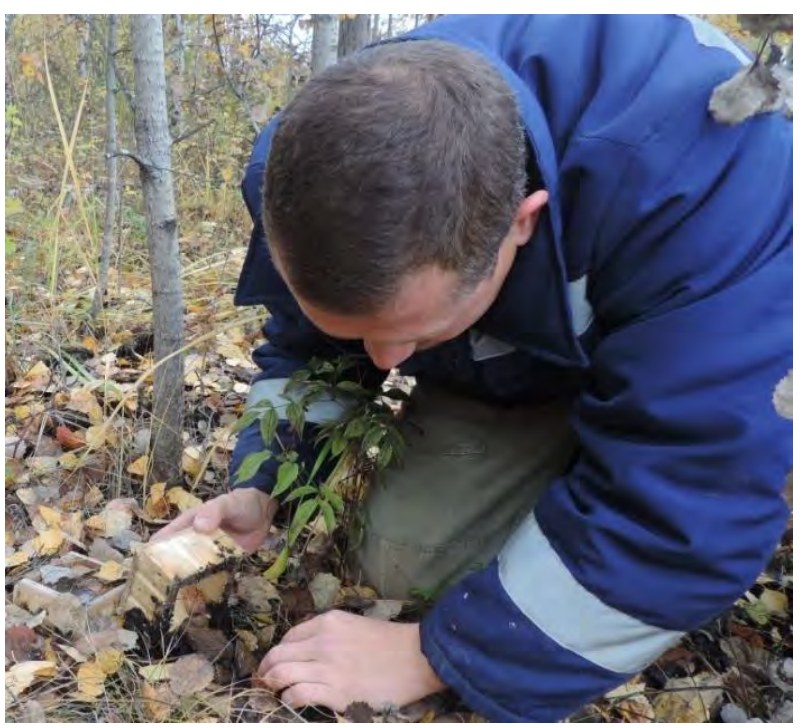

Fig. 4. Observation over female ticks 


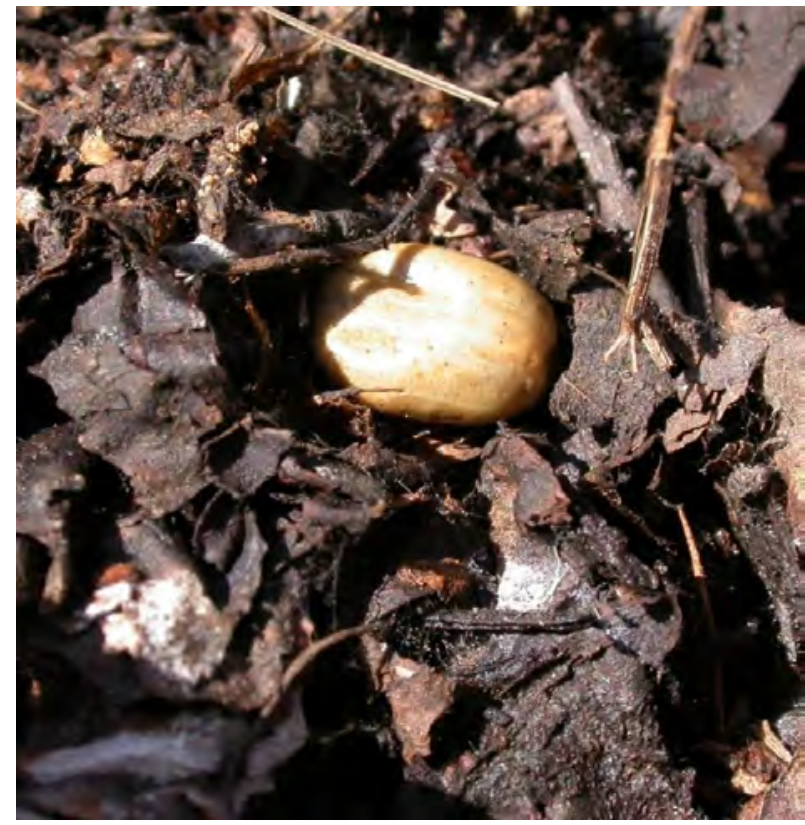

Fig. 5. Female D. reticulatus in forest litter

Considering negative meteorological factors which were characterized by heavy rains and low ambient temperature the terms of tick parasitizing in such conditions have been limited.The last active ticks in 2013 were caught in the nature on 29 September.Such behavior of female ticks was justified. In spite of the fact that the fall was long, air temperature had not been downto below $10^{\circ} \mathrm{C}$ up to December.

Weather conditions in winter months were standard for the region: the average air temperature was $-13,8^{\circ} \mathrm{C}$, the average indicator of atmospheric pressure was $755,2 \mathrm{~mm} \mathrm{Hg}$, the rainfall was $66 \mathrm{~mm}$, the snow cover depth was $26,5 \mathrm{~cm}$ that corresponds to normal climatic indexes forstudying region.

The observation over full females was continued at the beginning of theixodidticks activity season. The laying was checked on March 24, westatedthe existence of all bions in the cages showing life signs. At the same time no one female tick started the process of egg-laying. After opening the cages we continued daily observations over theticks, in the course of which we established the death of one female from the unknown wrecker (Figure 6), and three female ticks started theiregg-laying on 6 May.

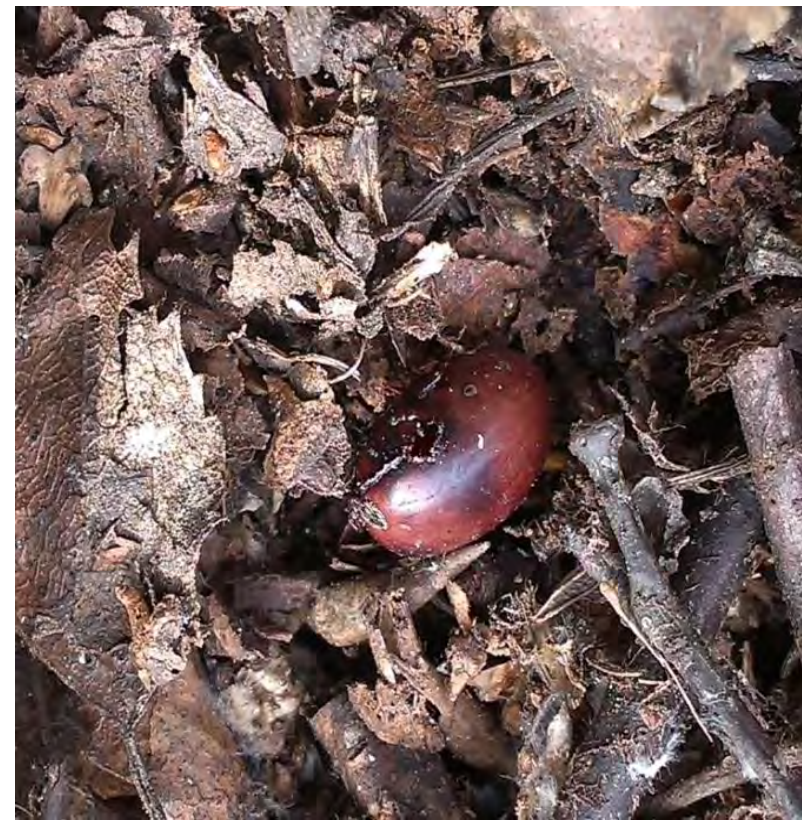

Fig. 6. Dead female tick

In 4 days (May10) two more female ticks started laying eggs, next day the other twofemale ticks startedlaying eggs (Figure 7-9)

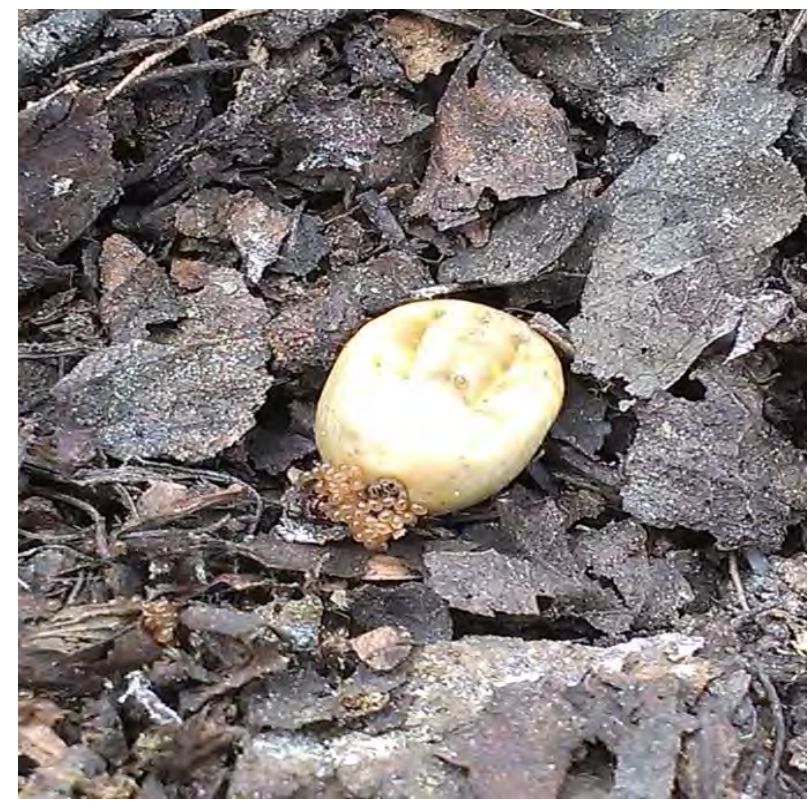

Fig. 7. The beginning of egg-laying 


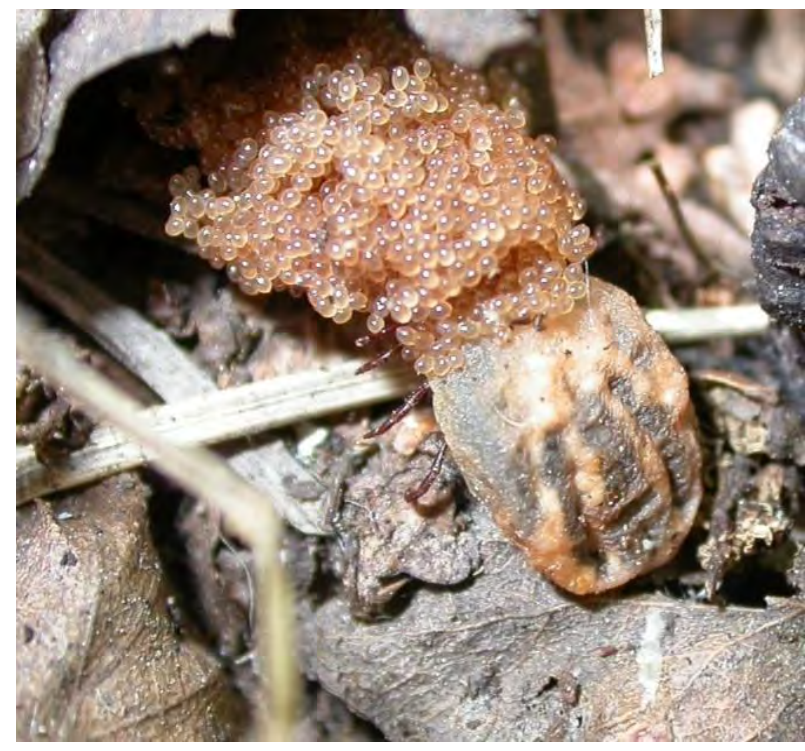

Fig. 8. Egg-laying by female D. reticulatus

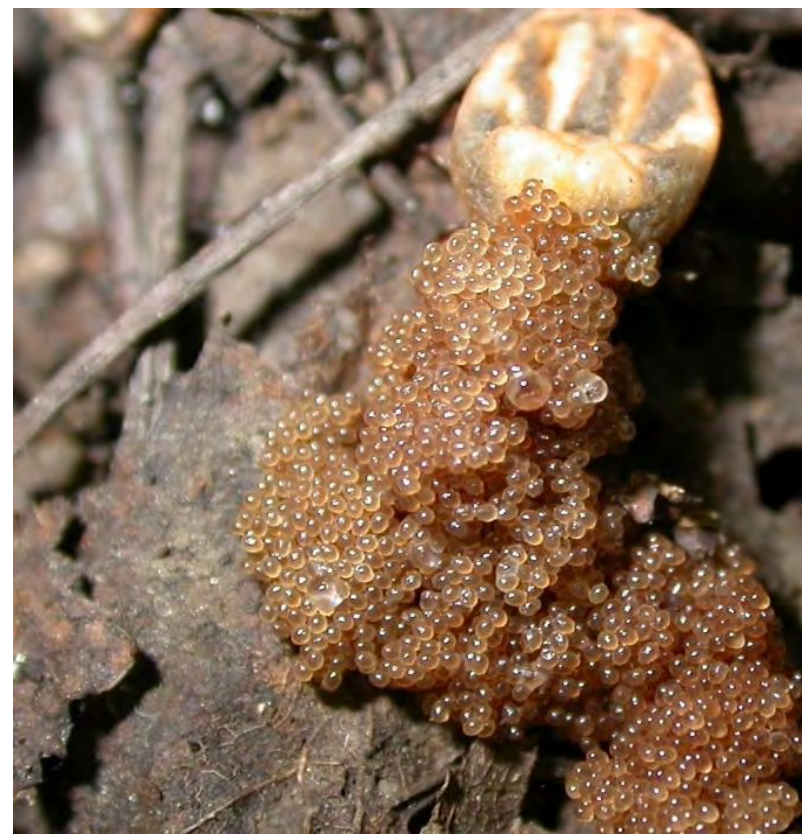

Fig. 9. Complete egg-laying

We have noted that females startedegg-laying only when the air temperature was stabilized at the level of $15,4-24,9^{\circ} \mathrm{C}$. The last alive female had fallen into diapause, it did not lay eggs during all season, and died at the end of the season. As a result,all 9 female ticks successfully overwintered, whereas only 7 females $(77,8 \%)$ laid eggs.

The duration of the separate stages of Dermacentor reticulatus development in natural conditions is presented in the table 1 . The table 1illustrates that the process of egg-layinghad lasted for 6-14 days, then the period of larvae formation had started and lasted for 11-26 days, the emerge of the first larvae was registered on June 01 . The process of larvae emerge had lasted for 23 days and finished on June 23(Figure 10-11).

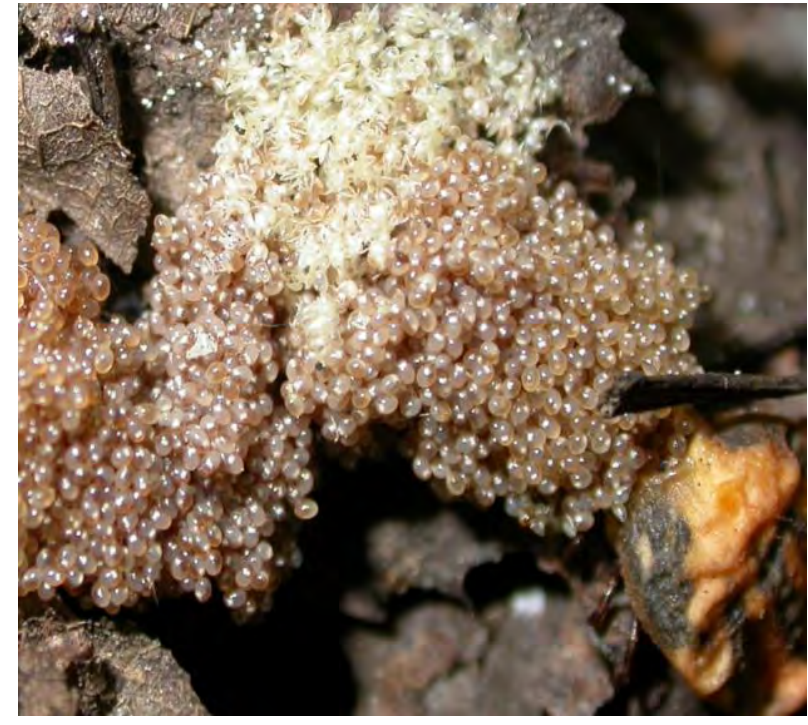

Fig. 10. Larvae emerge fromegg-laying

Table1 -The duration of particular stages of Dermacentor reticulatus developmentin natural conditions from 2013 to 2014.

\begin{tabular}{|c|c|c|c|c|c|}
\hline \multirow[t]{2}{*}{$\begin{array}{l}\text { Stage of } \\
\text { development }\end{array}$} & \multicolumn{3}{|c|}{$\begin{array}{c}\text { Duration of development, } \\
\text { full day }\end{array}$} & \multicolumn{2}{|c|}{$\begin{array}{l}\text { According } \\
\text { tolifestages }\end{array}$} \\
\hline & limits & $\begin{array}{l}\text { averagely, } \\
M \pm m\end{array}$ & $\%$ & days & $\%$ \\
\hline Egglaying & $6-14$ & $10.0 \pm 2.7$ & 8.7 & $10.0 \pm 2.7$ & 8.7 \\
\hline $\begin{array}{l}\text { Larva } \\
\text { metamorpho } \\
\text { sis } \\
\end{array}$ & $11-26$ & $18.5 \pm 4.8$ & 16.1 & \multirow[t]{2}{*}{$33.5 \pm 2.0$} & \multirow[t]{2}{*}{29.1} \\
\hline $\begin{array}{l}\text { Larva } \\
\text { emerge }\end{array}$ & $7-23$ & $15.0 \pm 2.0$ & 13.0 & & \\
\hline $\begin{array}{l}\text { Larva } \\
\text { feeding }\end{array}$ & $5-7$ & $6.0 \pm 1.0$ & 5.2 & \multirow{3}{*}{$34.5 \pm 2.3$} & \multirow{3}{*}{30.0} \\
\hline $\begin{array}{l}\text { Nymph } \\
\text { metamorpho } \\
\text { sis }\end{array}$ & $11-22$ & $16.5 \pm 3.6$ & 14.3 & & \\
\hline $\begin{array}{l}\text { Nymph } \\
\text { emerge }\end{array}$ & $9-15$ & $12.0 \pm 2.2$ & 10.4 & & \\
\hline $\begin{array}{l}\text { Nymphfeedi } \\
\text { ng }\end{array}$ & $7-18$ & $12.5 \pm 3.6$ & 10.9 & \multirow{3}{*}{$37.0 \pm 5.0$} & \multirow{3}{*}{32.2} \\
\hline $\begin{array}{l}\text { Imagometa } \\
\text { morphosis }\end{array}$ & $13-36$ & $24.5 \pm 6.5$ & 21.3 & & \\
\hline $\begin{array}{l}\text { Imagoemerg } \\
\text { e }\end{array}$ & - & - & - & & \\
\hline $\begin{array}{l}\text { Total period } \\
\text { of tick } \\
\text { development }\end{array}$ & $\begin{array}{l}69- \\
161\end{array}$ & $115.0 \pm 1.9$ & 100 & $115.0 \pm 6.4$ & 100 \\
\hline
\end{tabular}




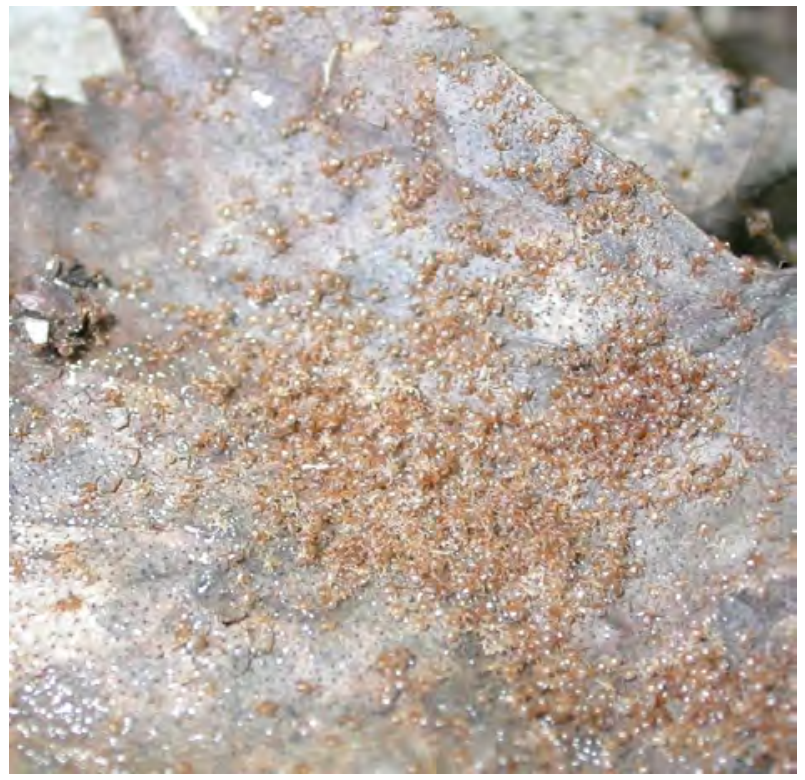

Fig. 11. Process of larvae grouping

ToactualizelifecyclesofDermacentorreticulatustheindividu alcageswithfemaleticksweredemountedandalllarvaewereunifie din one cage. The construction was strengthened by metalplatessinked $20 \mathrm{~cm}$ into the earth. To feed up larvae the white mice were put into the cage for 5-7 full days (Figure 1214).

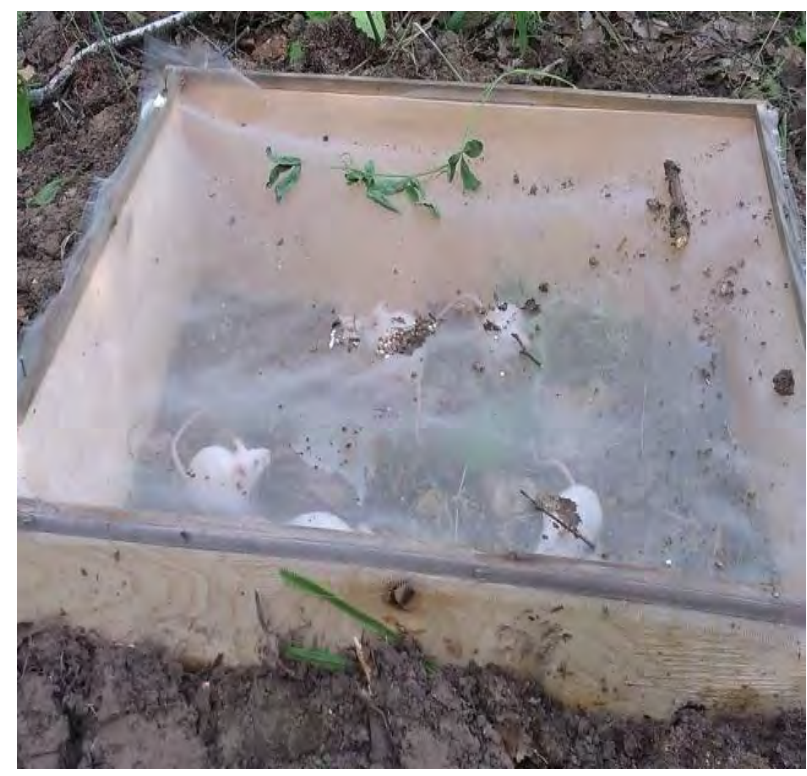

Fig. 12. The cage for feedingpre-imago ixodidae in the biotope

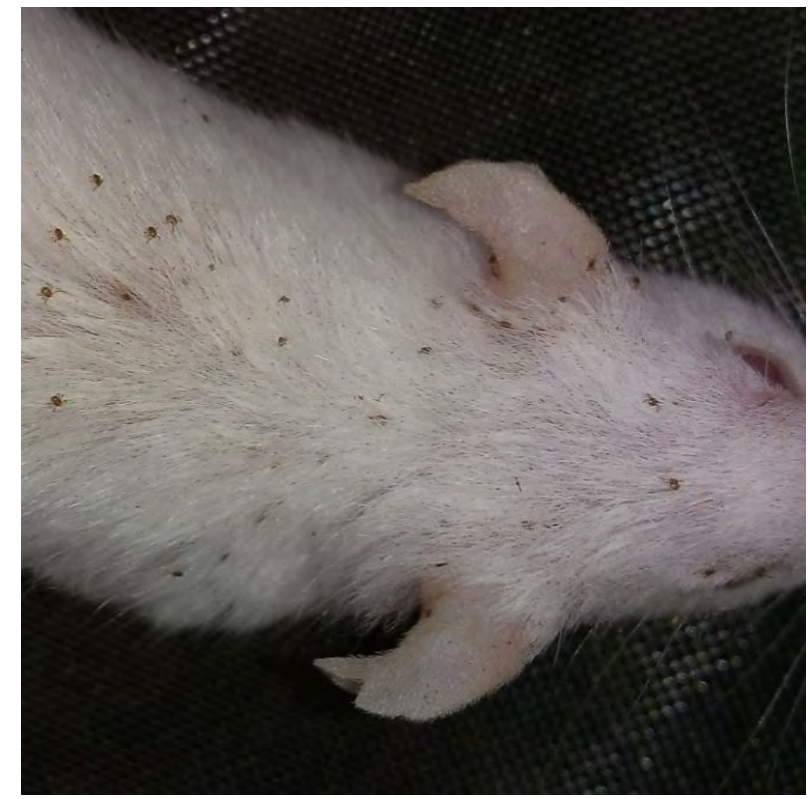

Fig. 13. Larvae creeping to the feeder

On the 8thdayofthe observation (June30) there were no any larvae on the mice (Figure14).

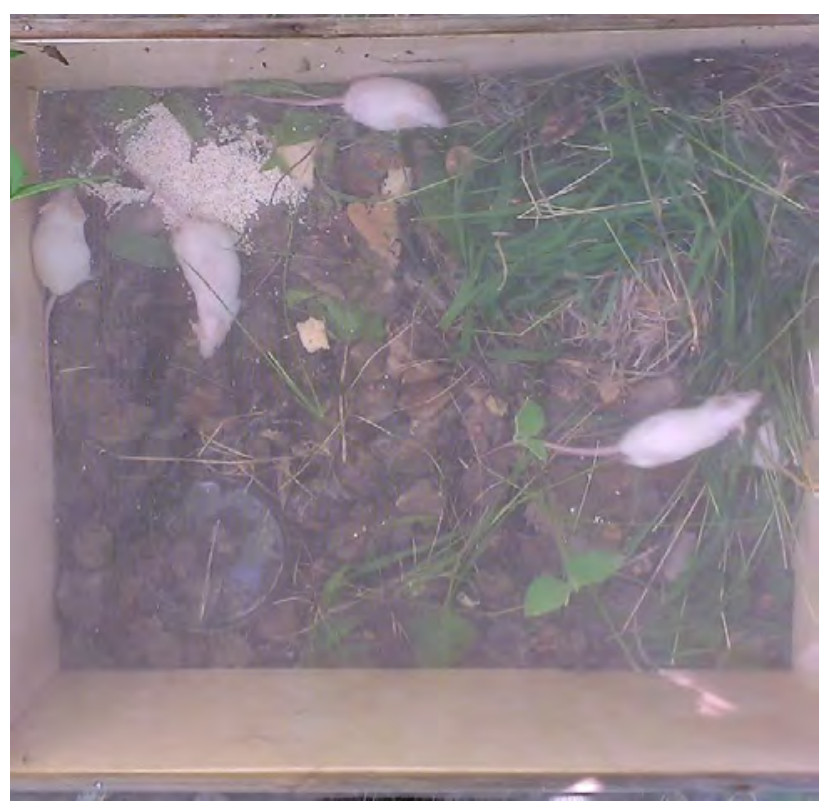

Fig. 14. Keeping feeders in the cage

Nymph metamorphosis from larvae had lastedfor 11-22 full days, then on July 8 we had noticed the nymph emerges in cage, which had lasted for 9-15 days and had finished on July 23. To feed up nymphs and continue their metamorphosis, we put white mice intothe cage on July 24 for 7-18 days as they were feeders for ixodidae atnymphal stage. We stopped feeding nymphs on 10 August. The imago metamorphosis had lasted for the most long time (13-36 full days), and the first adultshad appeared in the cage only on August 22, and theimago emergehad stoppedby September 4, i.e.ithad lasted for 13 days. 
Analyzing the data presented in table 1 wehave revealed that the duration of separate stages of D. reticulatus development is various. Thus, larva metamorphoses had taken the smallest time period $(29,1 \pm 2,0$ full days or $25,3 \%$ of all time of a cycle) in comparison with the other active phases of ixodidae formation. Nymph and imago formationshappened practically in equal periods of $34,5 \pm 2,3$ and $37,0 \pm 5,0$ full days respectively. We have noted that, Dermacentor reticulatus ticks are capable to give one generation for a parasitizing season ifparasite juvenile formsmeet feeders. All the process of reproduction from egg up to the emergence of an adult ticktakes from 69 to 161 days, and averagely $115 \pm 1,99$ full days. During the observation we noticed that the preimaginal stages of the D. reticulatus spend $18,5 \%$ of time in metamorphosis by eating on an animal (without imago feeding time).

\section{CONCLUSIONS}

In natural climate conditions of the Northern Trans-Ural region the Dermacentor reticulatus ticks are capable to give one generation for a parasitizing season on condition of meeting juvenile forms of a parasite with a feeder. All process of reproduction from egg up to the emergence of an adult tick takes from 69 to 161 days, averagely $115 \pm 1,99$ full days. Metamorphoses of larvae takes the smallest time period $29,1 \pm 2,0$ full days or $25,3 \%$ of all time of a cycle, the formation of nymphs and imagos happens practically in equal time periods of $34,5 \pm 2,3$ and $37,0 \pm 5,0$ full days respectively. Having studied these regularities of life cycles of the Dermacentor reticulates ticks of we can prove the emergence and the peaks of activity of both juvenile, and adult phases of these ticks activity that allows to plan actions for extermination of these parasites in places of their dwelling.

\section{Acknowledgment}

The article was prepared with the financial support of the Program of Fundamental Research of the Russian Academy of Sciences, registration number AAAA-A18-118020690240-3 "Monitoring of the epizootic situation and forecasts of the development of possible outbreaks of parasitic animal diseases".

\section{References}

[1] P. Bourdeau, T. Ximenes, O. Beziade, "Characteristics of Dermacentor reticulatus and Ixodes ricinus infestations in 191 dogs in France", Journal Veterinary Dermatology,vol.15, pp. 49, 2004.

[2] K. Brugger, M. Walter, L. Chitimia-Dobler, G. Dobler, F. Rubel, Prediction of Ixodes ricinus nymphal density next season: an example of southern Germany 2018.

[3] A. Buczek, Z. Zając, A. Woźniak, D. Kulina, K. Bartosik, "Locomotor activity of adult Dermacentorreticulatusticks (Ixodida: Ixodidae) in natural conditions", Ann Agric Environ Med. 2017 May 11;24(2):271275. doi: $10.5604 / 12321966.1230736$.

[4] Yu. V. Glazunov, L. A.Glazunova, "Changes of sexstructure of population of ixodid ticks under the action of abiotic factors", Journal of Pharmaceutical Sciences and Reserch, Vol. 10(1), 2018, pp. 129-131.

[5] Yu. V.Glazunov1, L. A.Glazunova, "Phenology of Pasture Ticks in The Trans-Urals", Indian Vet. J., January 2018, no. 95 (01) pp. 19 - 22.

[6] L. A. Glazunova, Yu. V Glazunov, A. A. Ergashev, "Ecologicalepizootical situation on telasiosis among large cattle in Northern Ural region", Research Journal of Pharmaceutical, Biological and Chemical Sciences.. Vol. 4. pp. 1687-1693, 2018.

[7] S. Hornok, M. L. Meli, E. Gönczi, R. Hofmann-Lehmann, "Seasonally biased or single-habitat sampling is not informative on the real prevalence of Dermacentor reticulatus-borne rickettsiae - A pilot study", Acta Vet Hung, 2017 Mar, no. 65(1), pp. 81-88. doi: 10.1556/004.2017.008.

[8] E. T. Machtinger, A. Y. Li, "Evaluation of four commercial natural products for repellency and toxicity against the lone star tick, Amblyomma americanum (Acari:Ixodidae)", Exp Appl Acarol, 2017, Dec, no. 73(3-4), pp. 451-460. doi: 10.1007/s10493-017-0185-z

[9] J. M. Medlock, K. M. Hansford, A. G. C. Vaux, B. Cull, S. Abdullah, M. E. Pietzsch, R. Wall, N. Johnson, L. P. Phipps, "Distribution of the tickDermacentorreticulatusin the United Kingdom", Med Vet Entomol, 2017,no. 31(3), pp. 281-288. doi: 10.1111/mve.12235

[10] G. M. Moraru, J. S. Portugal, A. Bednarova, S. J. Mcinnis, C. D. Paddock, T. Becker, T. C. Smith, Z. Svobodova, J. J. Goddard, "Morphometric Analysis of Adult Dermacentor parumapertus Neumann (Acari: Ixodidae), From Various Locations Within its Geographical Range", Med Entomol., 2018, no. 55(4), pp. 871-876. doi: 10.1093/jme/tjy009.

[11] E. Olivieri, A. L. Gazzonis, S. A. Zanzani, F.Veronesi, M.T.Manfredi,Seasonal dynamics of adult Dermacentorr eticulatusin a peri-urban park in southern Europe,"Ticks Tick Borne Dis", 2017,no. 8(5), pp. 772-779. doi: 10.1016/j.ttbdis.2017.06.002. Epub 2017 Jun 15.

[12] J. Radzijevskaja, D. Mardosaitè-Busaitienè, A. Aleksandravičienè, A. Paulauskas, "Investigation of Babesia spp. in sympatric populations ofDermacentorreticulatusand Ixodes ricinus ticks in Lithuania and Latvia", Ticks Tick Borne Dis., 2018, no. 9(2), pp. 270-274. doi: 10.1016/j.ttbdis.2017.09.013. Epub 2017 Sep 21.

[13] M. Selmi, L. Tomassone, L. A. Ceballos, A. Crisci, C. Ragagli, M. D. Pintore, W. Mignone, A. Pautasso, M. Ballardini, C. Casalone, A. Mannelli, "Analysis of the environmental and host-related factors affecting the distribution of the tick Dermacentor marginatus", Exp Appl Acarol., 2018, no. 75(2), pp.209-225. doi: 10.1007/s10493-018-0257-8.

[14] L. Skipin, E. Gaevaya, E. Zaharova, V. Petukhova, K. Sidorova "Biogeochemistry of heavy metals in trophic chain in terms of the south of Tumen region”, Procedia Engineering, Vol. 165. pp. 860-868, 2016.

[15] O.A. Stolbova, Yu.V. Glazunov, L.N. Skosyrskikh, "Ticks-parasites of dogs in Northern Trans-Urals", Indo American journal of pharmaceutical sciences. vol. 05 (03), pp.1675-1682, 2018.

[16] M. Yu. Tohou, S. N. Lutsuk, Yu.V. Dyachenko, Phenology of ticks of the genus Dermacentor in the Central Ciscaucasia, Parasitology, 2013, Vol. 47 , no. 6, pp. 437-447

[17] K. Vongphayloth, J. C. Hertz, K. Lakeomany, D. A. Apanaskevich, R. G. Robbins, I. W. Sutherland, P. T. Brey, "The Genus Dermacentor (Acari: Ixodidae) in Laos: A Review and Update of Species Records", J Med Entomol, 2018, no. 55(4), pp. 1047-1050. doi: 10.1093/jme/tjy041. 